\title{
副作用の少ない非ステロイド系抗炎症薬の開発への戦略
}

\author{
水島 徹
}

\section{A Strategy for Development of NSAIDs with Lower Risk for Side Effects}

\author{
Tohru Mizushima \\ Graduate School of Medical and Pharmaceutical Sciences, Research Institute for Drug Discovery, \\ Kumamoto University, 5-1 Oe-honmachi, Kumamoto City 862-0973, Japan
}

(Received August 22, 2007)

\begin{abstract}
Nonsteroidal antiinflammatory drugs (NSAIDs) are one of the most frequently used classes of medicines worldwide. The major clinical problem encountered with the use of NSAIDs is gastrointestinal complications. In the USA, about 16,500 people per year die as a result of NSAID-associated gastrointestinal complications. COX-2-specific NSAIDs have been developed as safer for the gastrointestinal tract, although the risk of cardiovascular thrombotic disease has recently been noted with the use of COX-2-specific NSAIDs. To find the strategy for the development of gastrointestinally safe NSAIDs other than COX-2-specific NSAIDs, we examined the molecular mechanism for NSAID-induced gastric ulcer formation. We found that NSAIDs induce gastric mucosal cell death in a manner independent of $\mathrm{COX}$ inhibition and that this cytotoxic effect is due to their membrane permeabilization activity, which is not required for the antiinflammatory activity of NSAIDs. Furthermore, we showed that in addition to COX inhibition by NSAIDs, direct cytotoxicity of NSAIDs is required for NSAID-induced gastric ulcer formation. These results suggest that NSAIDs that have neither membrane permeabilization activity nor COX-2 specificity would be safe for both the gastrointestinal tract and cardiovascular system and we are now chemically synthesizing such NSAIDs.
\end{abstract}

Key words_— nonsteroidal antiinflammatory drugs; gastrointestinal complication; membrane

\section{1. はじめに}

アスピリン，インドメタシンなどの非ステロイド 系抗炎症薬 (nonsteroidal antiinflammatory drugs; NSAIDs）は，優れた解熱・鎮痛・消炎薬として， 最もよく使われている医薬品の 1 つである. ${ }^{1)}$ それ はステロイドなど他の抗炎症薬に比べ，その副作用 が少ないなどNSAIDs が大変使い易いためである.

NSAIDs の市場は大変大きく，全世界で約 1 兆 5000 億円である. 特に高齢者に多く処方されるこ とから（イギリスでの調査では，65歳以上の患者 の $15 \%$ NSAIDs を使用していた)，今後この市場 は社会の高齢化に伴いさらに拡大すると思われる.

一方 NSAIDs の胃潰瘍誘発副作用が臨床現場で 大きな問題になっている（全米の1996 年の NSAIDs 潰瘍による死者は年間 16500 人で，エイズ

熊本大学大学院医学薬学研究部・創薬研究センター (T862-0973 熊本市大江本町 5-1)

e-mail: mizu@gpo.kumamoto-u.ac.jp

本総説は, 日本薬学会第 127 年会シンポジウム S41 で 発表したものを中心に記述したものである.
死亡者よりも多かつた). ${ }^{2)}$ わが国でも，NSAIDs 長 期服用者の 20-30\%は胃潰瘍のためにその使用を中 止しなければならないという統計が報告されてい る。近年胃潰瘍誘発副作用の少ない NSAIDs とし て，COX-2 選択的 NSAIDs が開発されたが，後述 するように，最近これにはその COX-2 選択性を原 因とする新たな副作用（血栓を起こし易くし心筋梗 塞を誘発する）があること，及び長期投与では従来 の NSAIDs と同程度の胃潰瘍誘発能を持つことが 報告され，COX-2 選択的 NSAIDs に代わる, 新し い胃潰瘍を起こさない NSAIDs の開発が社会的に 強く望まれている.

NSAIDs はシクロオキシゲナーゼ（COX）の阻 害剂であり，COX には COX-1 と COX-2 という 2 つのサブタイプが存在する. COX は生理活性物質 であるプロスタグランジン（PG）生合成の律速酵 素である。炎症部位において発現している COX は 主にCOX-2 であり，炎症部位で PG は炎症を増悪 している。そこで NSAIDs は COX-2 を阻害し PG を低下させることにより抗炎症作用を発揮してい 
る。一方胃粘膜では主に COX-1 が発現している. 胃粘膜で PG は, 胃粘膜を保護するという有益な働 きをしている. ${ }^{3,4)}$ アスピリン, インドメタシンなど の従来の NSAIDs は COX-1，及び COX-2 をとも に阻害するので，胃粘膜で PG を低下させるため， 胃潰瘍を導くと考えられていた。 そこで近年開発さ れたのが, COX-2 を選択的に阻害する COX-2 選択 的 NSAIDs（セレコキシブ，ロフェコキシブなど） である。わが国ではまだ認可されていないが, COX-2 選択的 NSAIDs は北米を中心に大変よく使 われており，セレコキシブ，ロフェコキシブはとも に年間 4000 億円以上売り上げている（ロフェコキ シブに関してはごく最近，その血栓誘発副作用のた め，市場から撤退した）。

しかし最近では，NSAIDs 潰瘍の発症がその COX 阻害作用のみでは説明できないと考えられる ようになってきた。例えばインドメタシンをラット に経口投与する場合，胃潰瘍を発症させるために必 要なインドメタシンの濃度は，胃粘膜の PG 合成を 完全に抑制するのに必要な濃度に比べ，10 倍以上 も高いことが知られている。このように NSAIDs 潰瘍の発症には, COX 阻害以外の別の作用も関与 していることが明らかになってきたが，この別の作 用が何であるかは不明であつた。われわれは NSAIDs が胃粘膜細胞を直接傷害する（胃粘膜細胞 死を導く）ことが，この別の作用の実体ではないか と考え，研究を開始した。

2. NSAIDs によるネクローシス，アポトーシス 誘導 $5-8)$

最初にわれわれは，生体内の胃粘膜細胞の状態を よく反映している（粘液産生が起こる，粘膜細胞へ の分化が起こるなど）モルモット胃粘膜初代培養細 胞を用いて，NSAIDs による細胞死を in vitro で再 現することを試みた. Figure 1 に示すように，種々 の濃度のインドメタシンで胃粘膜細胞を 1 時間又は 16 時間処理すると, 濃度依存的な細胞死が観察さ れ，インドメタシンによる細胞死を in vitro で再現 することに成功した. 処理時間の違いにより細胞死 に必要なインドメタシン濃度が異なっていたため, それぞれどのような細胞死が起きているのかを検討 した. その結果 Fig. 1 に示すように，アポトーシ スの特徴の 1 つである DNA 断片化, クロマチンの 凝集, カスパーゼの活性化は, 16 時間処理した細
胞では検出されたが，1 時間処理した細胞では検出 されなかった。したがってインドメタシンは, 低濃 度長時間処理時にはアポトーシスを, 高濃度短時間 処理時にはアポトーシス以外の細胞死，すなわちネ クローシスを誘導して胃粘膜細胞を直接傷害するこ とが分かった。 なお，使用しているインドメタシン 濃度は，通常の服用時の血中濃度に比べるとかなり 高いものの，胃内で溶解した場合の胃内濃度と同程 度と考えている。

次にわれわれはこの細胞死（アポトーシス，ネク ローシス）がNSAIDsのCOX 阻害作用とは無関係 （非依存）であることを確認するために実験を行い 以下に述べる 2 つの結果を得た。1つは，培地中に かなりの高濃度の PG を添加しても，この NSAIDs によるアポトーシス, 及びネクローシスが抑制され ないという結果, もう 1 つは, アポトーシス, 及び ネクローシスを誘導するために必要な NSAIDs の 濃度は, COX を阻害するために必要な濃度に比べ 10 倍以上高いという結果である。以上の結果は, NSAIDs によるアポトーシス, 及びネクローシス誘 導が，COX 阻害作用には依存していないことを示 している.

\section{NSAIDs による膜傷害作用9,10)}

アポトーシス，及びネクローシスに関する NSAIDs のターゲットがCOX ではないことが分か つたが，それではターゲットは何であろうか？わ れわれはNSAIDs が膜リン脂質と相互作用すると いう論文 ${ }^{11)}$ に注目し，NSAIDs が膜傷害性を持ち， これがアポトーシス, 及びネクローシス誘導の原因 ではないかと考えた。そこで 10 種類以上の NSAIDs を用いて，その膜傷害性とアポトーシス， 及びネクローシス誘導性の相関性を調べた。 その結 果，調べた限りすべての NSAIDs はアポトーシ ス, 及びネクローシスを誘導するだけでなく, 赤血 球からのへモグロビンの漏出を促進し膜傷害性を持 つことが分かった. さらに蛍光物質であるカルセイ ンを封入したリポソーム（リン脂質のみからなる）

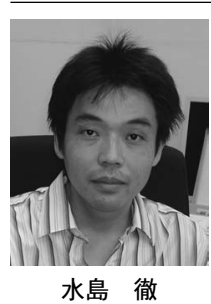

1990 年東京大学薬学部卒, 1992 年山之 内製薬侏研究員, 1994 年九州大学助手, 1997 年岡山大学助教授, 2004 年熊本大 学教授, 2006 年創薬研究センター長. 現在, LTT バイオファーマ侏取締役, 再春館製薬所侏技術アドバイザー, JST 開発責任者などを兼務. 

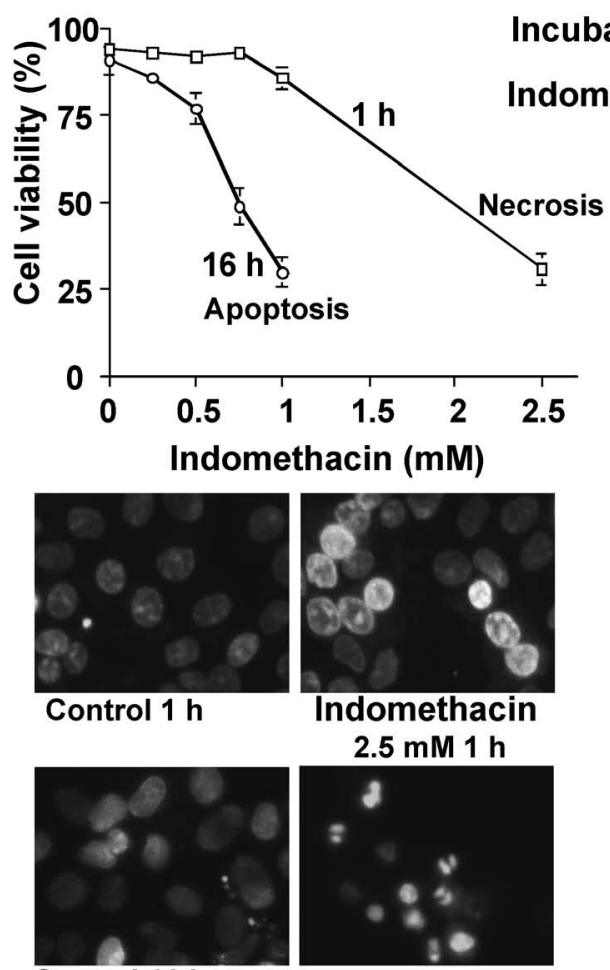

Control $16 \mathrm{~h}$

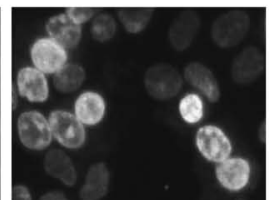

Indomethacin

$2.5 \mathrm{mM} 1 \mathrm{~h}$

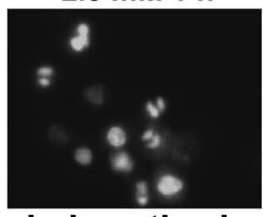

Indomethacin $1 \mathrm{mM} 16 \mathrm{~h}$
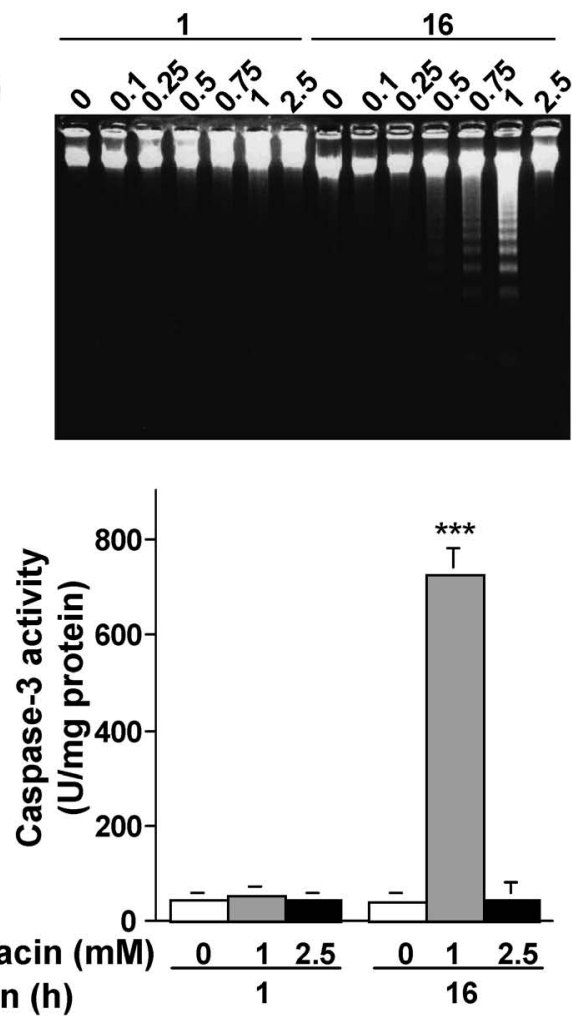

Fig. 1. Cultured Gastric Mucosal Cells Were Incubated with Indicated Concentrations of Indomethacin for $1 \mathrm{hr}$ or $16 \mathrm{hr}$. Cell viability was determined by the trypan blue exclusion test. Chromosomal DNA was extracted and analyzed by $2 \%$ agarose gel electrophoresis. After staining with both $\mathrm{Ho} 342$ and PI, cells were observed under fluorescence microscope. Cell lysates were prepared and their activity of caspase-3 was measured by fluorometric assay using Ac-DEVD-MCA. Values are mean \pm S.E. $(n=3)$.

を用いて，カルセインの漏出を指標とした膜傷害試 験を行った。その結果，すべての NSAIDs がカル セインを漏出させ，NSAIDs はリン脂質（細胞膜上 のタンパク質ではなく）をターゲットとして，膜傷 害を起こすことが分かった。 さらに Fig. 2 に示す ように，これら NSAIDsによる膜傷害性とアポ トーシス，及びネクローシス誘導性は大変よく相関 しており（Fig. 2)，NSAIDs はその膜傷害性を介し て，アポトーシス，及びネクローシスを誘導し，胃 粘膜細胞を直接傷害することが強く示唆された.

\section{NSAIDs 誘導性遺伝子の網羅的解析 ${ }^{12,13)}$}

細胞が強いストレスを受け細胞膜の機能が大きく 低下したとき，ネクローシスが起こると一般に考え られている。一方, 膜傷害がアポトーシスを誘導す る機構はよく分からなかった。そこでわれわれはア ポトーシスを誘導する条件で胃粘膜細胞を NSAIDs で処理し, 誘導される遺伝子をDNA チップを使つ て網羅的に解析した。その結果 GRP78 など，小胞 体ストレス応答（小胞体が傷害を受け小胞体内に変 性したタンパク質が蓄積すると誘導されるストレス
応答）に関与する遺伝子を複数同定し，NSAIDs が 小胞体ストレス応答を誘導することが初めて分かつ た. 最近小胞体ストレス応答誘導により，アポトー シス誘導性を持つ転写因子 $\mathrm{CHOP}$ が誘導されるこ とが報告された。そこでわれわれは NSAIDsによ るアポトーシス誘導が CHOP を介する可能性を考 え実験を行った。まずわれわれは，mRNA，及び タンパク質レベルで，種々の NSAIDs が CHOPを 誘導することを確認した。CHOP の誘導には, ATF6，ATF4，及び XBP-1 という 3 種の転写因子 が関与することが知られているが，われわれは種々 の NSAIDs によりこれらすべての転写因子が活性 化されることを示した。さらにこの NSAIDsによ る CHOP 誘導が NSAIDs によるアポトーシス誘導 に関与していることを以下の $2 つ の$ 実験で示した. まず CHOP のドミナントネガティブ変異タンパク 質を発現することにより，NSAIDs によるアポトー シス誘導が抑制されることを見い出した。さらに Fig. 3 に示すように, CHOP のノックアウトマウ スから調製した細胞では，NSAIDs によるアポトー 


$$
r^{2}=0.94
$$

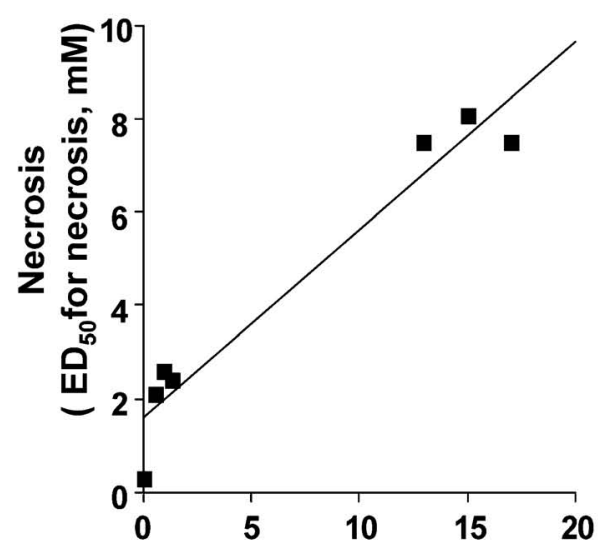

Membrane permeabilization $\left(\mathrm{ED}_{20}\right.$ for calcein release, $\left.\mathrm{mM}\right)$ $r^{2}=0.93$

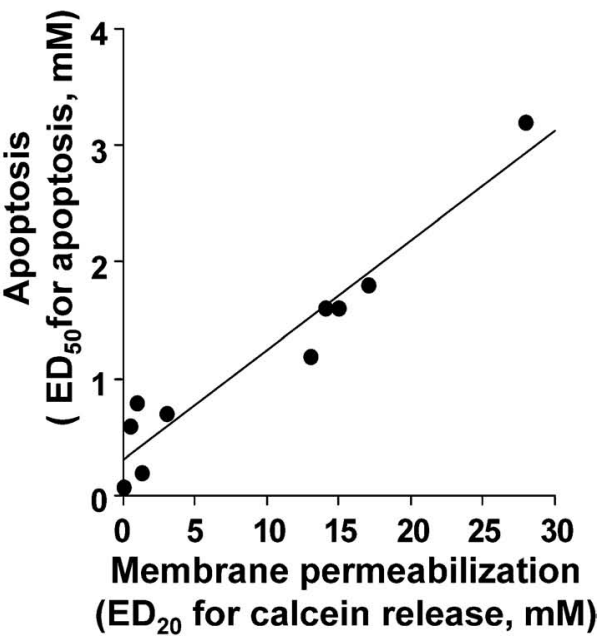

Fig. 2. $\mathrm{ED}_{20}$ Values for Membrane Permeabilization (calcein release), $\mathrm{ED}_{50}$ Values for Apoptosis and Necrosis Are calculated and Plotted

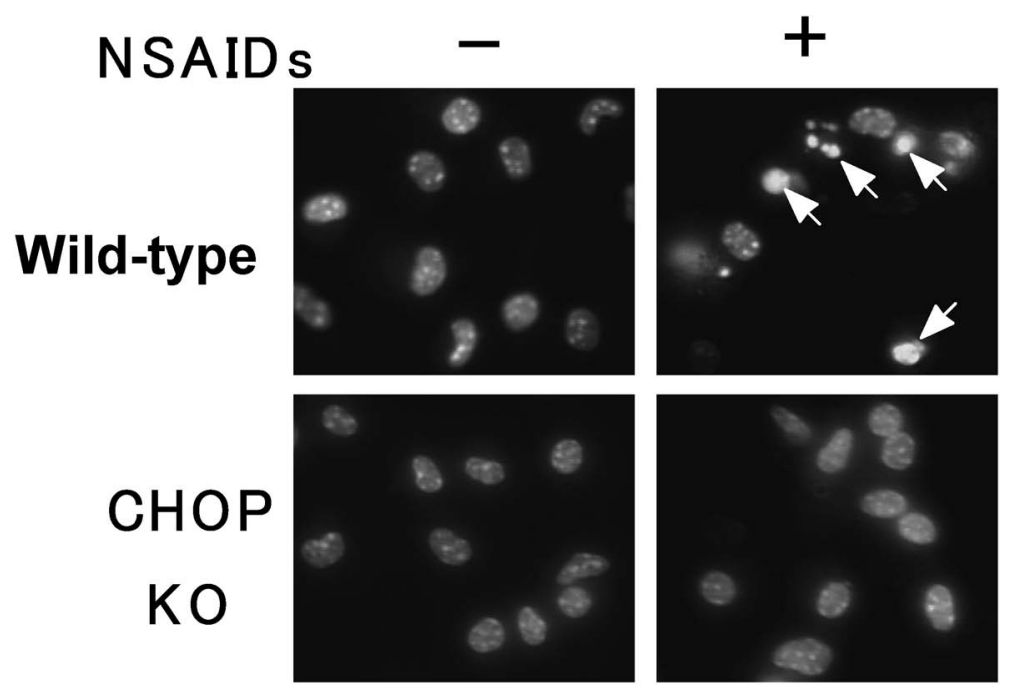

Fig. 3. Peritoneal Macrophages from Wild-type or CHOP Deficient Mice Were Treated with $1 \mathrm{~mm}$ Indomethacin for $24 \mathrm{~h}$ Cells were stained with Hoechst dye 33258 and observed under a fluorescence microscope. Arrows indicate condensed chromatins.

シス誘導が全くみられないことを示した。以上の結 果は，NSAIDs は小胞体ストレス応答 $(\mathrm{CHOP})$ を 誘導することにより，アポトーシスを起こすことを 示唆している.

それでは NSAIDs の膜傷害性がどのようなメカ ニズムで小胞体ストレス応答を誘導するのであろう か? われわれは細胞内カルシウム濃度上昇の関与 を考えた。それは細胞質膜の損傷により細胞外から 内へのカルシウムの流入が促進され, 細胞内力ルシ ウム濃度が上昇すること, 及びカルシウムイオノフ オアなどにより細胞内カルシウム濃度を上昇させた
とき，小胞体ストレス応答が誘導されることを根拠 としている，実際にわれわれは調べた限りすべての NSAIDs により細胞内カルシウム濃度が上昇するこ と，及び細胞内でカルシウムをキレートしその効果 を消失させる BAPTA-AM により， NSAIDsによ るアポトーシス誘導が抑制されることを見い出した (田中ら未発表)。以上の結果は，NSAIDs によるア ポトーシス誘導に, 細胞内カルシウム濃度の上昇が 関与していることを示している。 そこでわれわれは 現在，NSAIDs によるアポトーシス誘導は，細胞質 膜の傷害により細胞内カルシウム濃度が上昇し，そ 
の結果 CHOP が誘導されるために起こると考えて いる.

\section{NSAIDs 潰瘍発症機構6,14,15)}

以上の研究から， NSAIDs によるアポトーシス， 及びネクローシス誘導機構がある程度理解されるよ うになってきた。それでは，この NSAIDs による 直接細胞傷害（胃粘膜細胞死）は，胃潰瘍発症に本 当に関与しているのだろうか？われわれは， NSAIDs が胃潰瘍を導くためには，胃粘膜で COX を阻害し PG を低下させることに加え，NSAIDs に よる胃粘膜細胞死が必要であるという新しい仮説を 考えた。この仮説を証明するためにわれわれは，新 しい NSAIDs 潰瘍に関する動物モデルを考案し た。それは低用量インドメタシンの静脈注射と，細 胞傷害性のある COX-2 選択的 NSAIDs の経口投与 を組み合わせるモデルである．前述のように細胞傷 害に必要な濃度に比べ，インドメタシンの COX を 阻害するために必要な濃度は低い。そのため低用量 インドメタシンの静脈注射により，胃粘膜で COX を阻害し PG を低下させながら，細胞傷害は起こら ないようにすることができる。逆に細胞傷害性のあ る COX-2 選択的 NSAIDs の経口投与では，経口投 与なので胃内での NSAIDs の濃度はかなり高くな り細胞傷害は起こしながら，胃粘膜の PG を低下さ せないようにすることができる（胃粘膜で主に発現 しているCOX-1 は阻害しないため)。そこで仮に
われわれの仮説が正しく，すなわち NSAIDs が胃 潰瘍を導くためには，胃粘膜で COX を阻害し PG を低下させることに加え，NSAIDs による胃粘膜細 胞死が必要であるならば，低用量インドメタシンの 静脈注射，及び細胞傷害性のある COX-2 選択的 NSAIDs の経口投与，それぞれ単独では潰瘍は起こ さないが，両者を同時に投与すると胃潰瘍が発症す ることが予想される。実際 Fig. 4 に示すように, 低濃度インドメタシンの静脈注射，及びセレコキシ ブ（最も細胞傷害性の強い COX-2 選択的 NSAIDs） の経口投与を同時に行ったときのみ，胃潰瘍の発症 がみられた。 またセレコキシブの代わりにロフェコ キシブ（ほとんど細胞傷害性を持たない）を用いた 場合には，ほとんど胃潰瘍が発症しなかった。以上 の結果はわれわれの仮説の妥当性，すなわち NSAIDs が胃潰瘍を導くためには，胃粘膜で COX を阻害し PG を低下させることに加え，NSAIDs に よる胃粘膜細胞死が必要であることを示唆している.

\section{6. まとめと展望}

以上のわれわれの研究から，胃潰瘍を起こさない NSAIDs を開発するためには，膜傷害性（細胞傷害 性）のないNSAIDs，あるいは胃粘膜で PG を低下 させない NSAIDs を開発すればいいことが分か る。後者，すなわち胃粘膜で PG を低下させない NSAIDs が，COX-2 選択的 NSAIDs である。しか し前述のように最近, COX-2 選択的 NSAIDs は心
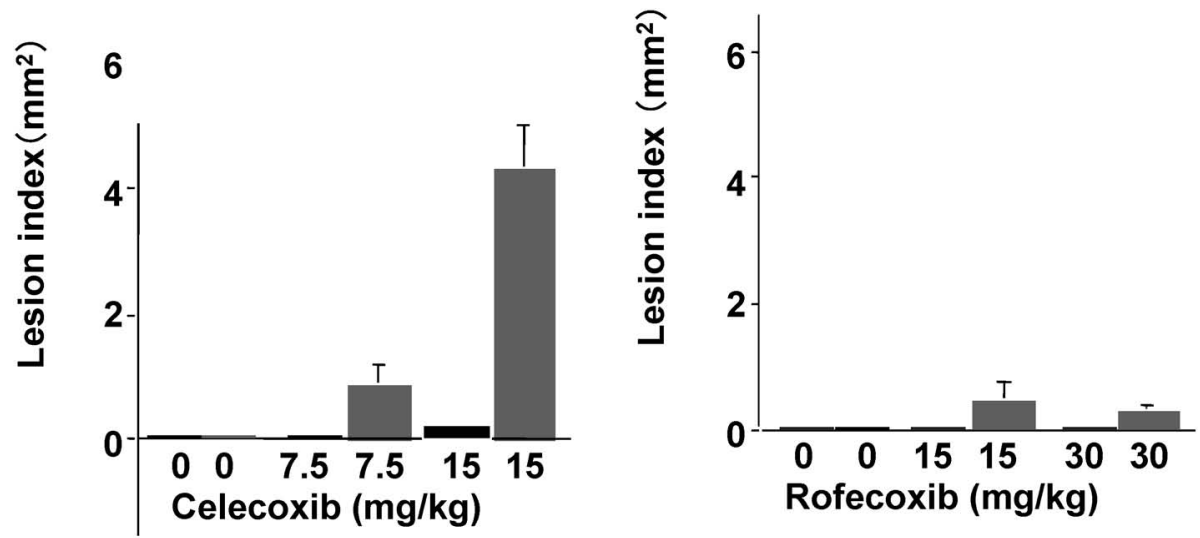

- indomethacin iv

\section{+ indomethacin iv}

Fig. 4. Rats Were Intravenously Administered with or without $3 \mathrm{mg} / \mathrm{kg}$ Indomethacin

After $1 \mathrm{~h}$, animals were orally administered with NSAIDs as indicated. After $6 \mathrm{~h}$, the stomach was removed and scored for hemorrhagic damage. Values are mean \pm S.E. $(n=6)$ 
筋梗塞を誘発するという衝撃的な論文が相ついで発 表された。血液凝固調節系において，COX-1 によ つて合成されるトロンボキサン $\mathrm{A} 2$ が血液凝固を促 進するのに対し，COX-2 によって合成されるプロ スタサイクリンは血液凝固を阻害する。そこで, COX-2 だけを阻害する COX-2 選択的 NSAIDs は，血液凝固を阻害するプロスタサイクリンだけを 減少させるために，血栓をでき易くするのである。 実際，COX-2 選択性のない従来の NSAIDs を使用 している患者に比べ，COX-2 選択的 NSAIDs を使 用している患者の心筋梗塞を起こす危険性は 5 倍以 上であるという臨床試験の結果が公表されている. また最近北米では，「心筋梗塞を起こす可能性のあ る患者には，COX-2 選択的 NSAIDsを使用しない ように」という注意文書が配布された。 さらに，代 表的な COX-2 選択的 NSAIDs であるロフェコキシ ブがその心筋梗塞誘発副作用のために販売停止とな つた。 そこで COX-2 選択性を高める以外の方法で,

NSAIDs 潰瘍を起こさない NSAIDs を開発する必 要がある。そこで注目されるのが膜傷害作用のない NSAIDs である。すなわち，COX-2 に対する選択 性がなく，かつ膜傷害性のない NSAIDs は，胃潰 瘍誘発副作用，及び心筋梗塞誘発副作用のない真に 安全な NSAIDs になる。われわれはこのような NSAIDs の発見を目指して現在そのスクリーニング を行っている.

これから開発しようしている NSAIDs を，われ われは第四世代の NSAIDs と位置付けている。 スピリン，インドメタシンなどの最初に開発された NSAIDs（第一世代の NSAIDs）の胃潰瘍誘発副作 用を少しでも減らそうとして，それをプロドラッグ 化（吸収されたあとで活性化されるように）したの が，ロキソニンやボルタレンなどの第二世代の NSAIDs である。しかしそれでも胃潰瘍誘発副作用 の問題が完全に解決されなかったので，第三世代の NSAIDs である COX-2 選択的 NSAIDs（ロフェコ キシブなど）が開発された。この第三世代の NSAIDs の登場により，胃潰瘍誘発副作用の問題は ほぼ解決されたが，一方での心筋梗塞誘発副作用と いう新たな副作用が生じた。そこでわれわれは，胃 潰瘍誘発副作用，及び心筋梗塞誘発副作用のない, 真に安全な NSAIDs（COX-2 に対する選択性がな く，かつ膜傷害性のない NSAIDs）を第四世代の
NSAIDs として開発しようと考えている.

\section{REFERENCES}

1) Smalley W. E., Ray W. A., Daugherty J. R., Griffin M. R., Am. J. Epidemiol., 141, 539545 (1995).

2) Singh G., Am. J. Med., 105, 31S-38S (1998).

3) Vane J., Nature, 367, 215-216 (1994).

4) Smith C. J., Zhang Y., Koboldt C. M., Muhammad J., Zweifel B. S., Shaffer A., Talley J. J., Masferrer J. L., Seibert K., Isakson P. C., Proc. Natl. Acad. Sci. U.S.A., 95, 1331313318 (1998).

5) Tomisato W., Tsutsumi S., Rokutan K., Tsuchiya T., Mizushima T., Am. J. Physiol. Gastrointest. Liver Physiol., 281, G1092-1100 (2001).

6) Tomisato W., Tsutsumi S., Hoshino T., Hwang H. J., Mio M., Tsuchiya T., Mizushima T., Biochem. Pharmacol, 67, 575-585 (2004).

7) Tsutsumi S., Namba T., Tanaka K. I., Arai Y., Ishihara T., Aburaya M., Mima S., Hoshino T., Mizushima T., Oncogene, 25, 10181029 (2006).

8) Namba T., Hoshino T., Tanaka K., Tsutsumi S., Ishihara T., Mima S., Suzuki K., Ogawa S., Mizushima T., Mol. Pharmacol., 71, 860870 (2007).

9) Tomisato W., Tanaka K., Katsu T., Kakuta H., Sasaki K., Tsutsumi S., Hoshino T., Aburaya M., Li D., Tsuchiya T., Suzuki K., Yokomizo K., Mizushima T., Biochem. Biophys. Res. Commun., 323, 1032-1039 (2004).

10) Tanaka K., Tomisato W., Hoshino T., Ishihara T., Namba T., Aburaya M., Katsu T., Suzuki K., Tsutsumi S., Mizushima T., J. Biol. Chem., 280, 31059-31067 (2005) .

11) Lichtenberger L. M., Wang Z. M., Romero J. J., Ulloa C., Perez J. C., Giraud M. N., Barreto J. C., Nat. Med., 1, 154-158 (1995).

12) Mima S., Tsutsumi S., Ushijima H., Takeda M., Fukuda I., Yokomizo K., Suzuki K., Sano K., Nakanishi T., Tomisato W., Tsuchiya T., Mizushima T., Cancer Res., 65, 1868-1876 (2005) .

13) Tsutsumi S., Gotoh T., Tomisato W., Mima 
S., Hoshino T., Hwang H. J., Takenaka H., Tsuchiya T., Mori M., Mizushima T., Cell Death Differ., 11, 1009-1016 (2004).

14) Aburaya M., Tanaka K., Hoshino T., Tsutsumi S., Suzuki K., Makise M., Akagi R., Mizushima T., J. Biol. Chem., 281, 33422-
33432 (2006).

15) Tanaka K., Tsutsumi S., Arai Y., Hoshino T., Suzuki K., Takaki E., Ito T., Takeuchi K., Nakai A., Mizushima T., Mol. Pharmacol., 71, 985-993 (2007). 